DOI: $10.19195 / 2084-5065.43 .6$

\title{
Jeszcze o propozycji zakotwiczenia w kodeksie karnym kryteriów obiektywnego przypisania skutku
}

\author{
RYSZARD DęBSKI \\ Katedra Prawa Karnego \\ Uniwersytet Łódzki
}

I. W pracach opublikowanych w ostatnich latach prof. T. Kaczmarek wielokrotnie opowiadał się za stanowiskiem, że obiektywne przypisanie skutku w prawie karnym musi mieć zarówno swe ontyczne, jak i normatywne podstawy. Dobitnie podkreślał tezę, iż

uznanie kogokolwiek za sprawcę prawnokarnie relewantnego skutku jest możliwe tylko wtedy, gdy da się wykazać, że określone zachowanie podmiotu stanowi w sensie czysto kauzalnym jego przyczynę (warunek ontologiczny), a nadto, gdy kauzalnie spowodowany skutek jest rezultatem zachowania społecznie nieakceptowanego (warunek normatywny) ${ }^{1}$.

Również w ramach dyskusji dotyczącej zgłaszanych w Komisji Kodyfikacyjnej Prawa Karnego propozycji wprowadzenia do kodeksu karnego znowelizowanych przepisów odwołujących się do normatywnych kryteriów przypisania prof. T. Kaczmarek jasno stwierdzał, iż zalicza się do zdecydowanych zwolenników nauki o obiektywnym przypisaniu skutku, że — jak podkreśla — opowiada się „po stronie zadeklarowanych zwolenników Zurechnungslehre”2. Stanowisko to pozwala niewątpliwie zaliczyć autora do wciąż rosnącej grupy polskich karnistów,

${ }^{1}$ Por. T. Kaczmarek, Wybrane aspekty ontologicznych i normatywnych podstaw przypisania skutku, „Kwartalnik Prawa Publicznego” 2004, nr 4, s. 8. Por. także: idem, Kryteria obiektywnego przypisania skutku jako problem kodyfikacyjny, [w:] Nauki penalne wobec szybkich przemian socjokulturowych. Księga jubileuszowa Profesora Mariana Filara, t. I, red. A. Adamski et al., Toruń 2012, s. 169-170; idem, Kryteria obiektywnego przypisania skutku jako problem kodyfikacyjny (głos przeciwko ich ustawowej regulacji), [w:] Obiektywne oraz subiektywne przypisanie odpowiedzialności karnej, red. J. Giezek, P. Kardas, Warszawa 2016, s. 148.

2 Por. np. J. Giezek, T. Kaczmarek, Przeciwko ustawowej regulacji kryteriów obiektywnego przypisania skutku, „Państwo i Prawo” 2013, nr 5, s. 79, 81. 
którzy nie bez racji — jak się wydaje — uważają, że argumenty zwolenników nauki o obiektywnym przypisaniu uznać należy za znacznie silniejsze od wątpliwości i zastrzeżeń podnoszonych przez przeciwników tej koncepcji.

Warto zaznaczyć, że chodzi tu o - już w dużej mierze okrzepłą naukowo, rozwijaną od lat zwłaszcza w piśmiennictwie niemieckojęzycznym — teorię obiektywnego przypisania skutku odnoszoną do ustalenia sprawstwa w ramach realizacji znamion przestępstw materialnych ${ }^{3}$. Nauka ta wyrosła na dość już obecnie oczywistym spostrzeżeniu, że w wypadku tzw. czystych (prostych) przestępstw skutkowych, przy których ustawa w swoim wyraźnym brzmieniu wymaga jedynie „spowodowania" szkodliwego skutku, do stwierdzenia wypełnienia znamion typu czynu zabronionego nie wystarczy ustalenie samego ,przyczynienia się", zbadanie związku przyczynowego na podstawie założeń teorii równowartości warunków. U podstaw nauki o obiektywnym przypisaniu skutku leży zatem — jak to stwierdza U. Kindhäuser — dzisiaj niemal jednomyślny pogląd, że niezbędnego ograniczenia odpowiedzialności w tych przypadkach poszukiwać należy — wbrew temu co dawniej uważano za wystarczające — nie jedynie (dopiero) w ramach strony podmiotowej czynu zabronionego albo winy, lecz częściowo już przy badaniu wypełnienia obiektywnych znamion typu czynu zabronionego 4 . Zgodnie z najbardziej lapidarnym uzasadnieniem, spotykanym w piśmiennictwie niemieckim, za przyjęciem założeń teorii obiektywnego przypisania skutku i odpowiednim ukształtowaniem normatywnych kryteriów przypisania przemawia potrzeba odróżnienia bezprawia (czynu bezprawnego) od nieszczęśliwego przypadku i konieczność odgraniczenia tych całkiem odmiennych zdarzeń już na płaszczyźnie

${ }^{3}$ Bogate w ostatnich latach piśmiennictwo dotyczące kryteriów przypisania skutku, szybki rozwój różnie pojmowanej nauki o przypisaniu, brak jednolitości stosowanej terminologii skłaniają do przypominania genezy omawianej koncepcji w jej „klasycznym” ujęciu, albowiem chodzi o naukę, której podwaliny w doktrynie niemieckiej położył już w latach 30 . XX w. R. v. Honig, a której rozwój (ponowne „narodziny”) — jako „nowej” nauki o obiektywnym przypisaniu — wiąże się z opublikowaniem opracowania C. Roxina z 1970 r. o przypisaniu w prawie karnym w księdze poświęconej R. v. Honigowi. Zgodnie z przyjętymi założeniami filtr przypisania miał spełniać funkcję ograniczającą przy pomocy kryteriów normatywnych - już na płaszczyźnie realizacji znamion typu czynu zabronionego (obiektywnej znamienności konkretnego czynu) — nazbyt szerokie ustalenia wynikające z teorii równowartości warunków (por. np. R. Rengier, Strafrecht. Allgemeiner Teil, München 2010, s. 78). To o ujmowanej w ten sposób nauce o obiektywnym przypisaniu mówi R. Rengier, iż jest ona tak rozpowszechniona w piśmiennictwie i nauczaniu akademickim, że można ją określić jednoznacznie jako pogląd dominujący (ibidem, s. 79). Por. na temat źródeł „klasycznego" ujęcia koncepcji obiektywnego przypisania np. R. Dębski, O potrzebie kodeksowych przepisów o obiektywnym przypisaniu skutku, [w:] Meandry prawa karnego i kryminalistyki. Księga jubileuszowa prof. zw. dra hab. Stanisława Pikulskiego, red. J. Kasprzak, W. Cieślak, I. Nowicka, Szczytno 2015, s. 71 n. Szeroko o źródłach teorii obiektywnego przypisania - por. J. Giezek, Przyczynowość oraz przypisanie skutku w prawie karnym, Wrocław 1994, s. 49 n.; idem, Teorie zwiąku przyczynowego oraz koncepcje obiektywnego przypisania, [w:] System Prawa Karnego, t. 3. Nauka o przestępstwie. Zasady odpowiedzialności, red. R. Dębski, Warszawa 2013, s. 450 n.

${ }^{4}$ U. Kindhäuser, Strafrecht. Allgemeiner Teil, Baden-Baden 2011, s. 88. 
obiektywnej $^{5}$. Z tak usytuowanymi kryteriami normatywnymi, służącymi ograniczeniu kręgu zachowań wypełniających znamiona przestępstw skutkowych, od lat wiązana jest koncepcja obiektywnego przypisania. Zastrzeżenie to jest o tyle istotne, że burzliwy w ostatnich dziesięcioleciach rozwój nauki o przypisaniu prowadził do formułowania różnych zapatrywań co do zakresu zastosowania konstruowanych koncepcji przypisania (od kryteriów odnoszonych początkowo tylko do przestępstw nieumyślnych, albo także do przestępstw z zaniechania i niektórych umyślnych, albo wszystkich skutkowych przestępstw umyślnych i nieumyślnych, a wreszcie również nie tylko do przestępstw materialnych) ${ }^{6}$. Kolejne etapy ewolucji koncepcji obiektywnego przypisania można obserwować także w polskim piśmiennictwie. Jak trafnie stwierdza P. Kardas — w ostatnich latach zauważyć można tendencję do zmiany charakteru koncepcji obiektywnego przypisania skut$\mathrm{ku}, \mathrm{z}$ odwołującej się pierwotnie do czysto przedmiotowo ujętego modelu normatywnych przesłanek przypisania skutku, w ujmowaną w sposób coraz bardziej uniwersalny - opartą na przesłankach zarówno przedmiotowych, jak i podmiotowych oraz subiektywnych — ogólną koncepcję ,przypisania odpowiedzialności za przestępstwo skutkowe"7. Znamienne dla tego kierunku jest stanowisko Sądu Najwyższego, zawarte w wielokrotnie analizowanym w piśmiennictwie ${ }^{8}$

5 J. Wessels, W. Beulke. H. Satzger, Strafrecht. Allgemeiner Teil, Heidelberg 2013, s. 70. Por. także R. Dębski, Czy zamieszczać w nowelizowanym kodeksie karnym przepisy o obiektywnym przypisaniu?, [w:] Polski proces karny i materialne prawo karne w świetle nowelizacji z 2013 roku. Księga jubileuszowa dedykowana Profesorowi Januszowi Tylmanowi z okazji Jego 90. urodzin, red. T. Grzegorczyk et al., Warszawa 2014, s. 386.

${ }^{6}$ Por. na ten temat np. R. Dębski, Pozaustawowe znamiona przestęstwa. O ustawowym charakterze norm prawa karnego i znamionach typu czynu zabronionego nie określonych w ustawie, Łódź 1995, s. 170 n. Warto zwrócić uwagę na słuszne spostrzeżenia — jak określają je J. Giezek i P. Kardas - prima facie terminologiczne. Chodzi o to, że pojęcie „przypisania” jest coraz częściej wykorzystywane w doktrynie i orzecznictwie w różnych kontekstach, wskazujących na konieczność dokonywania wielu ocen na poszczególnych płaszczyznach prawnokarnego wartościowania badanego zachowania. Mówi się zatem nie tylko o obiektywnym przypisaniu skutku, lecz o przypisaniu znamion czynu zabronionego, o przypisaniu odpowiedzialności karnej za skutek, o przypisaniu odpowiedzialności karnej za czyn zabroniony, o przypisaniu czynu, o przypisaniu winy (J. Giezek, P. Kardas, O kryteriach obiektywnego oraz subiektywnego przypisania z punktu widzenia podstaw odpowiedzialności karnej - uwagi wprowadzajace, [w:] Obiektywne oraz subiektywne..., s. 13-15). Trafnie również podnosi J. Majewski, że termin „obiektywne przypisanie skutku" nie jest w naszym piśmiennictwie używany jedynie dla oznaczenia znanej z nauki niemieckiej koncepcji przypisania skutku propagowanej zwłaszcza przez C. Roxina, lecz także — w szerszym rozumieniu — do określenia każdej procedury przypisania skutku przy użyciu jakichś kryteriów normatywnych (J. Majewski, Koncepcje obiektywnej przypisywalności skutku - żywotność i znaczenie we wspótczesnej polskiej nauce prawa karnego oraz wpływ na praktyke wymiaru sprawiedliwości w Polsce, [w:] Obiektywne oraz subiektywne..., s. 42-43).

${ }^{7}$ P. Kardas, W poszukiwaniu tzw. negatywnych przesłanek obiektywnego przypisania, [w:] Obiektywne oraz subiektywne..., s. 195.

8 Por. zwłaszcza A. Barczak-Oplustil, Glosa do postanowienia SN z dnia 15 lutego 2012 r., II KK 193/11, CzPKiNP 2012, nr 4; S. Tarapata, Gtos w sprawie „niebezprawnego naruszenia 
uzasadnieniu postanowienia z dnia 15 lutego 2012 r. (II KK 193/11), w którym w kontekście ustalania prawnokarnej odpowiedzialności za skutek wymienia się nie tylko wymóg takiego przyczynienia się, które w sposób istotny zwiększa ryzyko wystąpienia skutku, lecz także warunki związane ze szczególnym stopniem naganności czynu zasługującego na moralne potępienie ${ }^{9}$. W uzasadnieniu tym wskazuje się również na specyfikę przestępstw nieumyślnych, w przyypadku których — ze względu na brak podmiotowej komponenty negatywnej moralnej oceny czynu w postaci nagannego zamiaru lub nagannego celu działania — dla przyjęcia karygodnego przyczynienia się do powstania skutku niezbędne jest ustalenie, że sprawca swoim zachowaniem w sposób znaczący zwiększył ryzyko wystąpienia skutku stanowiącego znamię typu czynu zabronionego ${ }^{10}$.

Stwierdzić należy, że rozwój koncepcji przypisania skutku we wskazanym kierunku prowadzi do generowania nowych, istotnych problemów związanych przede wszystkim z odniesieniem kryteriów przypisania do struktury wewnętrznej przestępstwa (chodzi zwłaszcza o uwzględnienie ewentualnych elementów o charakterze podmiotowym, wzięcie pod uwagę kryterium karygodności oraz czynników wpływających na winę). Nasuwają się też wątpliwości dotyczące powiązania tych kryteriów z normą sankcjonowaną albo z normą sankcjonującą, a także inne komplikacje związane z pytaniem o uniwersalny charakter proponowanej konstrukcji albo o odniesienie zasad przypisania do poszczególnych odmian przestępstw skutkowych (umyślnych, nieumyślnych, z działania i z zaniechania) itd. Przy badaniu ,przypisania odpowiedzialności za przestępstwo skutkowe” przedmiotem rozważań — w miejsce kryteriów obiektywnego przypisania skut$\mathrm{ku}$ — stają się szerzej ujęte ogólne kryteria sprawstwa (skutkowego) czynu zabronionego, związane z zakresem zastosowania określonej normy sankcjonującej ${ }^{11}$. Uwzględnienie czynników subiektywnych (podmiotowych) wśród elementów decydujących o przypisywalności sprawstwa przestępstwa skutkowego powoduje że trudno nadal mówić o ,obiektywnym przypisaniu skutku”. Proponuje się zatem np. określenie „przypisywanie sprawstwa typu skutkowego”"12. Konsekwencje takiego „nadmiernego rozrostu” koncepcji obiektywnego przypisania skut$\mathrm{ku}$ przedstawiał ostatnio w naszym piśmiennictwie P. Kardas ${ }^{13}$. Autor słusznie

reguł postepowania z dobrem prawnym” (o przypadku tzw. „płonacego anioła”), CzPKiNP 2013, nr 2, s. 25 n.; M. Małecki, Z problematyki obiektywnego przypisania skutku (przypadek płonacego aniota), CzPKiNP 2013, nr 2, s. 43 n.

9 Uzasadnienie postanowienia SN z dnia 15 lutego 2012 r. (II KK 193/11), LEX 1212351.

${ }^{10}$ Ibidem.

11 Por. na ten temat M. Małecki, Zbiegi i kolizje przypisana skutku, [w:] Obiektywne oraz subiektywne..., s. $322 \mathrm{n}$.

12 S. Tarapata, Negatywne przesłanki przypisania sprawstwa przestepstwa skutkowego $w$ kontekście subiektywnych elementów odpowiedzialności karnej - zagadnienia wybrane, [w:] Obiektywne oraz subiektywne..., s. 394.

13 P. Kardas, op. cit., s. 184 n. 
podnosi w konkluzji, iż nowa tendencja do uniformizacji „,kryteriów przypisania odpowiedzialności za skutek związana z wykorzystywaniem w procesie przypisania elementów zaczerpniętych ze wszystkich płaszczyzn, nie została w sposób satysfakcjonujący dogmatycznie opisana" i nie wykazano, czy ten sposób podejścia wykazuje teoretyczne, dogmatyczne i prakseologiczne przewagi nad ujęciem klasycznym, rozróżniającym w szczególności płaszczyznę obiektywnego i subiektywnego przypisania ${ }^{14}$. W braku takich przewag warto - jak trafnie stwierdza P. Kardas - pozostać na gruncie klasycznego ujęcia nauki o obiektywnym przypisaniu ${ }^{15}$. Stanowisko to w pełni zasługuje na aprobatę. Należy stwierdzić, że obecnie wystarczający stopień naukowej dojrzałości i użyteczności praktycznej wykazuje analizowane od lat i budzące dzisiaj najmniej kontrowersji „klasyczne” ujęcie nauki o obiektywnym przypisaniu skutku.

II. Z prac T. Kaczmarka — wskazanych na początku tych uwag — wynika, iż jest on zdecydowanym zwolennikiem takiego właśnie „klasycznego” ujęcia koncepcji obiektywnego przypisania, teorii konstruowanej od lat w piśmiennictwie jako nauka sprzeciwiająca się czysto kauzalnemu ustalaniu sprawstwa skutku (stwierdzaniu znamienności czynu przy przestępstwach materialnych) i określająca kryteria normatywne, które pozwalają na korektę i racjonalizację obiektywnej odpowiedzialności za skutek ${ }^{16}$. Autor tych prac jednak równie zdecydowanie sprzeciwia się zakotwiczeniu tej koncepcji w kodeksie karnym, wprowadzaniu do ustawy kryteriów obiektywnego przypisania. W dyskusji nad nowelizacją przepisów kodeksu karnego T. Kaczmarek stanowczo odrzucał propozycję zamieszczenia w ustawie kilku norm odwołujących się do kryteriów przypisania w postaci przepisów projektowanych przez Komisję Kodyfikacyjną. Sprzeciw ten odnosi się również do jakichkolwiek innych przepisów dotyczących obiektywnego przypisania skutku. We wspólnej wypowiedzi z J. Giezkiem T. Kaczmarek podkreśla, że opowiada się przeciwko wprowadzaniu do ustawy kryteriów obiektywnego przypisania również „w jakimkolwiek innym kształcie"17. W ramach uzasadnienia swojego stanowiska podnosi, iż objaśnienie kryteriów obiektywnego przypisania skutku lepiej pozostawić nauce i orzecznictwu, niż dekretować sposób ich rozumienia przepisem ustawy ${ }^{18}$.

Z poglądem, że objaśnianie kryteriów obiektywnego przypisania stanowi zadanie doktryny i judykatury — a nie ustawodawcy — trudno się nie zgodzić. Łatwo sobie wyobrazić problemy, jakie spowodowałaby próba zamieszczenia w przepisach kodeksowych np. definicji winy oraz reguł i trybu jej ustalania. Nie znaczy to, iż wskazanie w art. $1 \S 3$ k.k., że przestępstwem jest tylko czyn zawiniony, po-

\footnotetext{
14 Ibidem, s. 211-212.

15 Ibidem, s. 212.

16 Por. przypis 1.

17 J. Giezek, T. Kaczmarek, op. cit., s. 91.

18 T. Kaczmarek, Kryteria... (2012), s. 188. Por. podobnie idem, Kryteria ... (2016), s. 158.
} 
winno spotkać się z zarzutami, że wobec niezakończonego rozwoju nauki o winie zamieszczenie w kodeksie tak sformułowanego przepisu jest „,przedwczesne”, że ustawa arbitralnie rozstrzyga spory związane z teoriami winy, że zamyka prowadzone w piśmiennictwie dyskusje dotyczące funkcji winy i sposobów jej badania. Wręcz przeciwnie - jeśli okazałoby się np., iż w praktyce stosowania przepisów karnych ocena zarzucalności czynu nie zawsze jest traktowana jako odrębne kryterium prawnokarnego wartościowania, wskazanie w ustawie na obowiązywanie zasady winy należałoby uznać za niezbędne. Jak wiadomo — problem wyznaczenia granicy neutralności ustawodawcy w sprawach objętych nierozstrzygniętymi sporami naukowymi od lat stanowi w piśmiennictwie przedmiot sporów i wątpliwości. O polemicznych wypowiedziach I. Andrejewa i W. Woltera, sformułowanych $\mathrm{w}$ tej kwestii w okresie prac kodyfikacyjnych prowadzonych w połowie poprzedniego wieku, pisał niedawno - w kontekście oceny propozycji Komisji Kodyfikacyjnej z ostatnich lat - L. Gardocki ${ }^{19}$. W polemice tej W. Wolter, podzielając co do zasady stanowisko I. Andrejewa, że w przygotowywanym kodeksie karnym nie powinny być rozstrzygane kwestie sporne objęte dyskusjami teoretyków, wskazuje jednak — jak się wydaje — trafnie, iż istnieje granica takiej neutralności ustawodawcy, że należy jednak ustawowo rozstrzygać te kwestie, które już do tego dojrzały ${ }^{20}$. Oczywiście ocena stopnia rozwoju, „dojrzałości” ustaleń nauki w danej kwestii prowadzić może do istotnej różnicy zdań. Wydaje się wszakże, iż można uznać, że podstawowe ustalenia nauki o obiektywnym przypisaniu skutku osiągnęły już ten właśnie „dojrzały” stopień i że zachodzi potrzeba zaznaczenia w ustawie konieczności wartościowania (przez sąd) obiektywnej więzi łączącej zachowanie sprawcy z zabronionym w ustawie skutkiem. Mają rację ci autorzy, którzy podnoszą, że regulacje ustawowe nie powinny być oparte na takich hipotezach badawczych, które nie zostały dostatecznie naukowo zweryfikowane ${ }^{21}$. Takiego zarzutu jednak teorii obiektywnego przypisania skutku postawić nie można. Ponadto — jak trafnie podnosi M. Małecki — nie istnieje niebezpieczeństwo, że ustawodawca swoją decyzją ostatecznie rozstrzygnie spory naukowe i zamknie dyskusję na temat przypisywalności skutku, albowiem oparcie danej instytucji prawnej na jednej z koncepcji teoretycznych nie oznacza, iż inne koncepcje stają się nieprawdziwe lub niefunkcjonalne, że nie mogą nadal podlegać

19 L. Gardocki, O przenoszeniu poglądów teoretycznych do przepisów karnych, [w:] Zagadnienia teorii i nauczania prawa karnego. Kara łaczna. Księga Jubileuszowa Profesor Marii Szewczyk, red. W. Górowski et al., Warszawa 2013, s. 124.

${ }^{20}$ Ibidem. Jak podnosi L. Gardocki — mimo zgody, iż dyskusja na temat winy nie przyniosła jeszcze rezultatu, który nadawałby się do utrwalenia w ustawie, zamieszczono jednak w art. 2 § 3 projektu kodeksu karnego z 1956 roku przepis ograniczony do ogólnego stwierdzenia, że „nie ma przestępstwa bez winy”. L. Gardocki jest natomiast zdania, ze kwestia obiektywnego przypisania na pewno nie dojrzała jeszcze do zadekretowania w ustawie (ibidem, s. 140).

21 Trafnie na ten temat M. Małecki, Ustawowa regulacja kryteriów przypisania skutku (analiza wybranych uwag krytycznych), „Państwo i Prawo” 2015, nr 8, s. 102. 
rozważaniom i polemikom naukowym. Konsekwencje działań ustawodawcy mogą natomiast wywrzeć odmienny skutek, stanowiąc inspirację do zintensyfikowania badań teoretycznych nad danym zagadnieniem ${ }^{22}$.

III. Nasuwa się zatem pytanie, czy rezygnując z szczegółowego określania — różnorodnie nazywanych i niejednolicie wyodrębnianych w nauce — kryteriów obiektywnego przypisania skutku, nie powinno się zamieścić w ustawie karnej przepisu wskazującego na konieczność stosowania kryteriów normatywnych przy ustalaniu sprawstwa szkodliwego skutku. O ile bowiem bogate piśmiennictwo - zwłaszcza niemieckojęzyczne - nie doprowadziło wciąż do sformułowania uzgodnionej listy szczególnych kryteriów obiektywnego przypisania, o tyle stwierdzić trzeba, że zasadnicze tezy tzw. objektive Zurechnungslehre uznać można za szeroko w doktrynie aprobowane. W konsekwencji w większości podręczników opublikowanych w krajach, w których autorzy od lat zajmują się nauką o przypisaniu skutku (przede wszystkim chodzi o karnistów niemieckich i austriackich), nie pomija się ani nie kwestionuje istotnego znaczenia naukowego założeń tej koncepcji (także w pracach przedstawicieli doktryny nienależących do jej zwolenników). Zauważyć można, że również ogólne warunki przypisania skutku — nie zawsze tak samo nazywane i jednakowo charakteryzowane - powtarzają się w opracowaniach wielu autorów. Pozwala to na odróżnienie w piśmiennictwie ustaleń objętych znacznym zakresem aprobaty od kwestii wysoce kontrowersyjnych, będących przedmiotem szczególnego zróżnicowania zapatrywań. Zaznaczyć trzeba, że aprobata podstawowych założeń nauki o obiektywnym przypisaniu skutku nie musi się wiązać z przyjęciem skompletowanego i uporządkowanego katalogu przesłanek przypisania.

Należy zgodzić się ze stanowiskiem, iż dostrzeżenie wad opierania systemu prawa karnego wyłącznie na kauzalności i stwierdzenie potrzeby wprowadzenia normatywnych kryteriów oceny warunków przyczyniających się do skutku nie są wyłączną zasługą nauki o obiektywnym przypisaniu skutku ${ }^{23}$. Choć przyznać trzeba, że twórcy tej teorii w szczególnie wyrazisty sposób wykazali niedostatki „klasycznego” systemu prawa karnego z przełomu XIX i XX wieku, który właśnie - jak stwierdza C. Roxin — ustawową określoność czynu opierał na pojęciu kauzalności ${ }^{24}$. W istocie, potrzebę badania związku normatywnego między zachowaniem się a skutkiem wykazywać można również na innej drodze, niż czynią to zwolennicy objektive Zurechnungslehre ${ }^{25}$. Nie należy jednak nie doceniać

22 Ibidem, 101.

23 Por. Ł. Pohl, Prawo karne. Wykład części ogólnej, Warszawa 2015, s. 131.

24 C. Roxin, Problematyka obiektywnego przypisania, [w:] Teoretyczne problemy odpowiedzialności karnej w polskim oraz niemieckim prawie karnym, red. T. Kaczmarek, Wrocław 1990, s. 5.

25 Ł. Pohl normatywne podstawy obiektywnego przypisania skutku w prawie karnym wyprowadza z warunków wstępnych racjonalnego normowania zachowań ludzkich w normach prawnych (Ł. Pohl, op. cit., s. 131). 
znaczenia normatywnej selekcji podstaw obiektywnego przypisania skutku, ani też nie dostrzegać niesłusznego bagatelizowania lub kwestionowania tego znaczenia w części wypowiedzi krytycznych formułowanych przez oponentów nauki o obiektywnym przypisaniu. Chodzi o zapatrywania wyrażane zwłaszcza w polskim piśmiennictwie, w którym spotkać można nie tyle koncepcje poszukujące konkurencyjnych teorii wobec nauki o przypisaniu skutku, ile nierzadko „zachowawcze" poglądy, zgodnie z którymi ustawowa istota przestępstwa materialnego opiera się na kauzalności, a do ustalenia realizacji znamion typu czynu polegającego na „spowodowaniu” szkodliwego skutku odwołać się należy do teorii ekwiwalencji. Trafnie J. Majewski zwraca uwagę, iż w odniesieniu do stopnia rozpracowania tematu obiektywnej przypisywalności skutku w polskiej nauce prawa karnego sytuacja jest istotnie odmienna niż w piśmiennictwie niemieckojęzycznym ${ }^{26}$. Znane są np. formułowane w naszym orzecznictwie stanowcze wypowiedzi, zgodnie z którymi za najwłaściwszą metodę przypisywania szkodliwej zmiany w świecie zewnętrznym podmiotowi podejmującemu działanie uznaje się stosowanie (zgodnie z teorią równowartości warunków) testu conditio sine qua non. Jego zasadniczymi walorami są — jak twierdzi się niekiedy — prostota, jasność i niezawodność, a wszelkie obawy dotyczące zbyt szerokiego pola odpowiedzialności za skutek „W wystarczającym stopniu łagodzi i wręcz niweluje subiektywna przesłanka odpowiedzialności, tzn. wina"27. Lektura orzeczeń najwyższej instancji sądowej z ostatnich lat wskazywać może, iż „koncepcja obiektywnego przypisania skutku (Zurechnungslehre) na trwałe weszła już do orzeczniczego kanonu Sądu Najwyższego"28. Trafne jest jednak spostrzeżenie, że pojawiające się coraz częściej orzeczenia Sądu Najwyższego, odwołujące się do kryteriów obiektywnego przypisania, nie przesądzają jeszcze o ugruntowaniu się założeń tej

26 J. Majewski, op. cit., s. 45.

27 Por. na przykład znane wypowiedzi Sądu Najwyższego zawarte w postanowieniu z dnia 21 lutego 2001 r. (IV KKN 189/00). W postanowieniu tym Sąd Najwyższy stwierdza, że „problematyka związku przyczynowego należy do jednego z trudniejszych problemów w prawie karnym. $Z$ różnych rozwiązań tej kwestii praktyka dawno już za najwłaściwszą uznała teorię równowartości zwaną także teorią ekwiwalencji. Według tej teorii za przyczynę następstwa uważać należy każdy warunek, którego hipotetyczna eliminacja prowadzi do odpadnięcia danego następstwa w jego konkretnej postaci. [...] Niewątpliwym walorem takiego rozwiązania jest — jak podkreślano w doktrynie (m.in. W. Wolter, Nauka o przestępstwie, Warszawa 1973, s. 70-71; J. Śliwowski, Prawo karne, Warszawa 1975, s. 87) — prostota, jasność i niezawodność, gdy chodzi o prawidłowe ustalenie więzi przyczynowej. Obawy, iż koncepcja taka wyznacza zbyt szerokie pole odpowiedzialności karnej w wystarczającym stopniu łagodzi i wręcz niweluje subiektywna przesłanka odpowiedzialności tzn. wina sprawcy". Por. także inne, podobne wypowiedzi formułowane w polskim piśmiennictwie i orzecznictwie, przytaczane np. w R. Dębski, Czy zamieszczać..., s. 392-394.

28 D. Tokarczyk, Koncepcja obiektywnego przypisania skutku (uwagi na marginesie postanowienia Sądu Najwyższego), „Państwo i Prawo” 2015, nr 4, s. 65. 
teorii w orzecznictwie polskich sądów karnych ${ }^{29}$. W piśmiennictwie wskazywane są przykłady orzeczeń sądowych (również sądów apelacyjnych), w których — jak stwierdza P. Góralski — ,zastosowano tradycyjne kryteria związku przyczynowego, którego zakres był limitowany zasadą winy"30. Można zatem powiedzieć, iż w orzecznictwie brak w omawianej kwestii jednolitego stanowiska. Również w piśmiennictwie spotkać można wypowiedzi zwolenników „tradycyjnej” metody ustalania powiązań zachowania ze skutkiem wypełniających znamiona materialnego typu przestępstwa. Niekiedy podnosi się wątpliwość, „czy stosowana z powodzeniem przez szereg lat koncepcja ekwiwalencji, z korekturą w zakresie zawinienia [...], nie odpowiada lepiej potrzebom prawa karnego, niż nawiązująca do cywilistycznej koncepcji przeciętnej przyczynowości teoria obiektywnego przypisania"31. W ramach argumentacji krytycznej wobec pomysłu wprowadzenia do kodeksu karnego konstrukcji tzw. obiektywnego przypisania skutku, przywołuje się czasem wypowiedzi autorów formułowane w pierwszej połowie XX wieku. Chodzi np. o zamieszczony w komentarzu do kodeksu karnego z 1932 r. pogląd J. Makarewicza, zgodnie z którym związek przyczynowy w prawie karnym taktować należy tak, jak przedstawia się on w świecie przyrody, a granicą karalności i granicą odpowiedzialności za odległe od działania skutki przestępcze jest zasada subiektywizmu ${ }^{32}$.

IV. Należy stwierdzić, że w ostatnich dziesięcioleciach w wyniku intensywnego rozwoju (zwłaszcza w literaturze niemieckojęzycznej) nauki o obiektywnym przypisaniu skutku, lecz także wcześniejszych, wieloletnich badań nad koncepcją norm, potrzebę stosowania kryteriów normatywnych przypisania skutku uznać można obecnie za szeroko uznawaną w piśmiennictwie. Niezbędności odpowiedniego wartościowania ,warunków koniecznych” przed przypisaniem skutku nie kwestionują również przedstawiciele nauki odnoszący się krytycznie do koncepcji obiektywnego przypisania, sceptyczni wobec potrzeby konstruowania odrębnego stopnia-kryterium obejmującego zintegrowany zespół warunków tworzących filtr służący ustalaniu sprawstwa. Także ci autorzy, którzy oponują przeciwko tworzeniu takiego „obciążonego wieloma ocenami”, wyodrębnionego kryterium, nie proponują powrotu do czysto kauzalnie ustalanej znamienności czynu ${ }^{33}$, lecz przyznają, że „rozpoznanie” sprawstwa nie może opierać się wyłącznie na ustaleniach

29 P. Góralski, Związek przyczynowy w prawie karnym na tle orzecznictwa sądowego, „Prokuratura i Prawo" 2009, nr 6, s. 41.

30 Ibidem, s. 41-42.

31 Ibidem, s. 44.

32 W. Kozielewicz, Kilka uwag o wptywie doktryny prawa karnego i orzecznictwa sądowego na zmiany w prawie karnym na przyktadzie pomystu wprowadzenia do kodeksu karnego konstrukcji tzw. obiektywnego przypisania, [w:] Reforma prawa karnego materialnego i procesowego z 2015 roku. Wybrane zagadnienia, red. D. Kala, I. Zgoliński, Warszawa 2015, s. 24.

33 Choć — jak powiedziano — w ten sposób można odczytywać niektóre wypowiedzi spotykane w polskim piśmiennictwie. 
nauk przyrodniczych, że wymaga odwołania się do kryteriów normatywnych ${ }^{34}$. Znakomitą okazję do poznania skondensowanych argumentów wysuwanych przez krytyków nauki o obiektywnym przypisaniu stwarzały referaty niemieckich uczonych, wygłoszone na konferencji na temat obiektywnego i subiektywnego przypisania, która zorganizowana została we Wrocławiu w maju 2014 roku przez Katedrę Prawa Karnego Uniwersytetu Wrocławskiego oraz Komisję Legislacyjną Naczelnej Rady Adwokackiej ${ }^{35}$. Przedstawiony przegląd krytycznych opinii w tej kwestii pozwala zauważyć, że autorzy odrzucający — wbrew stanowisku przeważającemu w piśmiennictwie - koncepcję obiektywnego przypisania wysuwają zarzuty o różnej wadze, zróżnicowanej argumentacji i ,zasięgu rażenia" ${ }^{\text {36 }}$. W ramach formułowanych w literaturze niemieckiej wypowiedzi krytycznych wobec Zurechnungslehre podnosi się przede wszystkim, iż nauka o obiektywnym przypisaniu, pretendując do ogólnego określenia obiektywnych właściwości czynu uzasadniających przypisanie skutku, w istocie łączy — niejednolicie określane i należące

34 Por. krytyczne stwierdzenia F.-Ch. Schroedra na temat koncepcji obiektywnego przypisania i uwagi o konieczności stosowania kryteriów normatywnych przy prawniczych decyzjach wiązanych dawniej jedynie z ustaleniami empirycznymi czy opartymi na wiedzy przyrodniczej - F.-Ch. Schroeder, Der gegenwärtige Stand der Lehre über die objektive Zurechnung und die Möglichkeit oder Notwendigkeit der gesetzlichen Regelung ihrer Kriterien, [w:] Obiektywne oraz subiektywne..., s. 143.

35 Materiały z tej konferencji zamieszczono w zbiorze Obiektywne oraz subiektywne...

36 W ramach krytyki Zurechnungslehre podnoszony jest m.in. zarzut, iż koncepcja obiektywnego przypisania skutku opiera się — w pierwszym etapie badania — na ustaleniu związku przyczynowego przy wykorzystaniu teorii ekwiwalencji (równowartości warunków), która oparta jest na wadliwych logicznie założeniach. Argument ten bez wątpienia nie spodoba się tym wypowiadającym się zwłaszcza w polskim piśmiennictwie — krytykom nauki o obiektywnym przypisaniu, którzy uważają za zbędne sięganie do skomplikowanych i wciąż „niepewnych” kryteriów przypisania skutku, skoro można posłużyć się po prostu „sprawdzoną” teorią równowartości warunków i stosowanym w jej ramach, dającym pewne rezultaty, „rzetelnym” i skutecznym testem conditio sine qua non. Krytykując naukę o obiektywnym przypisaniu, K.H. Gössel jako pierwsze zastrzeżenie wobec tej koncepcji podnosi właśnie znany zarzut K. Engischa przeciwko teorii ekwiwalencji. K. Engisch (już w 1931 roku) stwierdzał, iż teoria ekwiwalencji oparta jest na klasycznym błędzie logicznym. Ma on postać błędnego koła polegającego na tym, że na wstępie zakłada się przyczynowość (powiązanie przyczynowe) tego warunku, którego charakter przyczynowy powinien być najpierw wykazany (dowiedziony), alowiem tylko wówczas gdy się wie, że pomiędzy badanym zdarzeniem (przyczyną) a daną zmianą (skutkiem) istnieje związek przyczynowy, można stwierdzić, iż bez badanego warunku zmiana by nie wystąpiła. Skoro z góry zakłada się przyczynowość jakiegoś zdarzenia wobec danej zmiany (skutku), to przy użyciu takiej koncepcji każde dowolne zdarzenie można uznać za przyczynowe wobec każdego „skutku”. Prowadzi to do nieograniczonego rozprzestrzeniania się pola w ten sposób określanej przyczynowości i do dowolności ustalanych rezultatów, zwłaszcza przy atypowych przebiegach przyczynowych. Zatem - jak stwierdza K.H. Gössel — załamują się także podstawy nauki o obiektywnym przypisaniu. Żadnej teorii nie można budować na logicznie błędnym ustaleniu, które przenosi się dalej na kolejne etapy rozstrzygania o przypisaniu skutku. Por. K.H. Gössel, Empfiehlt es sich, die Lehren der objektiven Zurechnung zu kodifizieren oder sollte die Möglichkeit erhalten bleiben, andere Lehren zu diesem Problembereich zu entwickeln und anzuwenden?, [w:] Obiektywne oraz subiektywne..., s. 120-121. 
do różnych płaszczyzn wartościowania - heterogenne cechy (znamiona) czynu przestępnego, tworzące kalejdoskop różnorodnych warunków, które ograniczają zespół znamion typu czynu ${ }^{37}$; że czyni to bez należytego rozróżnienia i przyporządkowania stawianych warunków do poszczególnych kryteriów oceny badanego zdarzenia; że usiłuje sprowadzić liczne proponowane przez siebie heterogenne propozycje wartościowań do jednej formuły, przy której zastosowaniu nie uzyskuje się w istocie rezultatów innych niż przy odwołaniu się do tradycyjnych, od lat stosowanych teorii ${ }^{38}$. Zarzuca się nauce o obiektywnym przypisaniu niezrozumiałe posługiwanie się kryterium sprowadzenia niedozwolonego niebezpieczeństwa, pomimo że również stworzenie dozwolonego niebezpieczeństwa może doprowadzić do zrealizowania zabronionego skutku ${ }^{39}$. Podnosi się wreszcie, iż odwołuje się ona do logicznie błędnej teorii równowartości warunków ${ }^{40}$, a przede wszystkim — że bezprawność wypełniającego znamiona naruszenia dobra prawnego zwolennicy tej koncepcji uzasadniają bezprawnością podjętego zachowania (naruszania), wpadają zatem w pułapkę błędnego koła ${ }^{41}$, albowiem — jak stwierdza K.H. Gössel — to właśnie przekroczenie normy powoduje, że dające się uniknąć zachowanie człowieka (zarówno naruszające dobro chronione, jak i narażające je na niebezpieczeństwo) staje się bezprawne. Traktowanie zabronionego zachowania (bezprawnego sprowadzenia niebezpieczeństwa) jako przesłanki stwierdzenia zakazanego przez normę zachowania (spowodowania szkodliwego skutku) prowadzi do rozumowania w postaci błędnego koła, zgodnie z którym zabronione zachowanie stanowi warunek uznania zachowania za zabronione, bezprawność staje się przesłanką siebie samej ${ }^{42}$. Najogólniej sformułowany zarzut przeciwników Zurechnungslehre dotyczy tego, że nauka o obiektywnym przypisaniu zbiera w jedną grupę różnorodne przypadki, które można rozwiązać w sposób słuszny i właściwy przy użyciu dotychczasowego instrumentarium, bez potrzeby odwoływania się do niejasnego pojęcia „obiektywnego przypisania”, które — jak twierdzi F. Zieschang — więcej zaciemnia, niż rozjaśnia ${ }^{43}$.

Nie ma tu, w krótkim artykule, miejsca na podejmowanie szerszej analizy zarzutów podnoszonych przez przeciwników nauki o obiektywnym przypisaniu skutku. Trudno skrótowo przedstawiać np. argumenty polemiczne, wskazujące — jak się wydaje — na potrzebę odróżnienia „niebezpieczności” samego czynu, jako ocenianej ex ante właściwości podjętego zachowania się (jego szkodliwości

37 Por. K.H. Gössel, op. cit., s. 121 n.; F. Zieschang, Der gegenwärtige Stand der deutschen Strafrechtswissenschaft zur Lehre von der objektiven Zurechnung, [w:] Obiektywne oraz subiektywne..., s. 54.

38 F.H. Schroeder, op. cit., s. 144.

39 K.H. Gössel, op. cit., s. 124-125.

40 Por. przypis 36 .

${ }^{41}$ K.H. Gössel, op. cit., s. 125.

42 Ibidem, s. 125-126.

43 F. Zieschang, op. cit., s. 69. 
ze względu na cechującą go „skutkonośność”), od zabronionego spowodowania szkodliwego skutku (w postaci stwierdzanego ex post naruszenia albo zagrożenia chronionego dobra). Zrozumiałe jest, że cecha bezprawności nie jest właściwością skutku (to nie szkodliwa zmiana w świecie zewnętrznym narusza normę postępowania). Cecha ta związana jest, rzecz jasna, z czynem człowieka, zachowaniem stanowiącym przekroczenie zakazu (postępowaniem wbrew dyrektywnie płynącej z normy). Karalność czynu może być uzależniona od wystąpienia szkodliwej zmiany w świecie zewnętrznym. Natomiast stwierdzenie, iż podjęte zachowanie stwarzało (lub zwiększało) w sposób niedopuszczalny niebezpieczeństwo spowodowania takiej (szkodliwej) zmiany, pozwala na ustalenie cechy prawnej wadliwości zachowania jako czynu przekraczającego normę postępowania. To, że zakaz działania wykazującego nadmierną, zabronioną „niebezpieczność” dla dobra chronionego (zachowania przekraczającego regułę postępowania wobec dobra), wynika z tej samej normy, która zakazuje „,sprowadzenia” szkodliwego skutku, nie oznacza, że ustalenia dotyczące niedopuszczalności zachowania się oraz szkodliwości sprowadzenia zabronionej zmiany (szkodliwego skutku) traktować należy jako jedną, zintegrowaną ocenę. Nie wydaje się zatem, aby należało upatrywać błędu logicznego w uzależnieniu karalności naruszenia (zagrożenia) przedmiotu ochrony od tego, czy skutek ten spowodowany został zachowaniem naruszającym regułę postępowania wobec dobra chronionego, czy też - postępowaniem w pełni dopuszczalnym (legalnym, choć powodującym szkodliwy skutek). Nie podejmując w tym miejscu polemiki z argumentami przeciwników Zurechnungslehre, stwierdzić jedynie należy, iż ci autorzy, którzy wyraźnie kwestionują omawianą teorię, zdecydowanie opowiadają się — co zrozumiałe — przeciwko zakotwiczaniu w ustawie w jakiejkolwiek formie kryteriów obiektywnego przypisania. Jeśli w poszukiwaniu alternatywnych rozwiązań odrzucają oni naukę o obiektywnym przypisaniu skutku, podając $\mathrm{w}$ wątpliwość jej podstawowe założenia, to oczywistą konsekwencją jest zdecydowany sprzeciw wobec zamieszczenia w kodeksie karnym przepisów nawiązujących do tej koncepcji ${ }^{44}$. Nie wydaje się jednak, aby taki sprzeciw — podyktowany szczególną ostrożnością — ze strony autorów zaliczających się do zwolenników teorii obiektywnego przypisania skutku można było uznać za wystarczająco uzasadniony.

V. Jak wiadomo — w niemieckojęzycznym piśmiennictwie od lat trwają dyskusje wokół przydatności, znaczenia i kryteriów obiektywnego przypisania skutku. Podstawowe argumenty przemawiające za koncepcją obiektywnego przypisania wynikają z oczywistych mankamentów czysto kauzalnego pojmowania istoty czynu, zwłaszcza w wypadku przestępstw nieumyślnych. Liczni zwolennicy nauki o obiektywnym przypisaniu skutku zapewne zdają sobie sprawę z tego, iż nie chodzi tu o teorię pozbawioną wad. Jej walor polega na tym, iż wykazuje ona mniej

44 Por. np. K.H. Gössel, op. cit., s. 139; F.H. Schroeder, op. cit., s. 145. 
wad od innych proponowanych rozwiązań. Niezależnie od tego, że polemizować z niektórymi zarzutami wobec teorii obiektywnego przypisania skutku nie jest łatwo, trudno nie dostrzec użyteczności stosowania w praktyce kryteriów proponowanych w ramach tej nauki. Toteż z braku lepszych koncepcji należy ją rekomendować - jak się wydaje - również jako punkt odniesienia do uregulowań kodeksowych. Nie należy oczekiwać, iż w najbliższych latach polemiki dotyczące przesłanek obiektywnego przypisania skutku ustaną, że różnice zdań znikną, a wszystkie wątpliwości zostaną wyjaśnione. Toczone w doktrynie prawa karnego spory, zwłaszcza te związane z ustaleniami odnoszącymi się do kryteriów wartościowania czynów na poszczególnych płaszczyznach struktury przestępstwa, ciągną się — jak uczy doświadczenie — przez dziesiątki lat. Powoli i sukcesywnie choć nie bez kolejnych zwrotów — budują one naukę o przestępstwie, porządkując kryteria oceny konkretnych zdarzeń i dostarczając odpowiednich narzędzi praktyce wymiaru sprawiedliwości. Zrozumiała jest pewna nieufność wobec bujnie ${ }^{45}$ rozwijającej się w ostatnich dziesięcioleciach nauki o obiektywnym przypisaniu. Wydaje się ona uzasadniona w stosunku do każdej nowej teorii, przede wszystkim zaś wobec koncepcji w istotny sposób ingerującej w starannie uprzednio ułożony porządek kryteriów oceny czynów. Nieufność ta może prowadzić — jak to się dzieje w nauce niemieckojęzycznej — do pogłębionej analizy krytycznej. Może również inspirować do poszukiwania rozwiązań alternatywnych. Niewątpliwie koncepcje te - w wypadku procedury ustalania sprawstwa - uwzględniać powinny konieczność stosowania odpowiednich kryteriów normatywnych już na szczeblu weryfikacji wypełnienia obiektywnych znamion typu czynu zabronionego $^{46}$. Nie wydaje się natomiast właściwa, spotykana w naszym piśmiennictwie, postawa „zachowawcza”, która zakłada, że wystarczy poprzestać na ustaleniu na płaszczyźnie „ontologicznej” — związku przyczynowego pomiędzy zachowaniem się określonej osoby a szkodliwym skutkiem i na oparciu stwierdzenia realizacji ustawowych znamion skutkowego typu czynu zabronionego na kauzalności zachowania. Przeciwko takiej czysto kauzalnej rekonstrukcji zespołu znamion skutkowego typu czynu zabronionego przemawiają nie tylko znane od lat ustalenia nauki, wynikające z wieloletnich badań nad istotą sprawstwa nieumyśl-

$45 \mathrm{Z}$ pewną tendencją do nadmiernego rozrostu w odniesieniu zarówno do zakładanego zasięgu zastosowania, jak i katalogu kryteriów (por. m.in. trafne uwagi w tej sprawie P. Kardasa, op. cit., s. 201-212).

$46 \mathrm{Z}$ punktu widzenia potrzeby przejrzystości procedury stosowania przepisów karnych w praktyce wymiaru sprawiedliwości poszukiwanie właściwych przesłanek racjonalizujących obiektywną odpowiedzialność za skutek jedynie we wstępnych warunkach normowania (tj. w warunkach wstępnych racjonalnego normowania zachowań ludzkich w normach prawnych) nie wydaje się rozwiązaniem oferującym kryteria bardziej czytelne niż podstawowa formuła koncepcji obiektywnego przypisania skutku. Chodzi bowiem o stosowanie takich kryteriów, które - powołane w uzasadnieniu decyzji sędziowskiej — byłyby dostatecznie klarowne także dla adresatów rozstrzygnięcia. 
nych czynów zabronionych, a następnie — badań dotyczących normatywnej charakterystyki zachowań sprawców przestępstw umyślnych. Zasadnicze argumenty przeciwko czysto kauzalnemu pojmowaniu istoty czynu zabronionego wynikają przede wszystkim z szeroko aprobowanych tez wywodzonych $\mathrm{z}$ teorii norm oraz z założonych funkcji przepisów prawa karnego.

Sięgając do historii krytyki naukowej „ujęcia kauzalnego”, można w tym miejscu odnotować kolejne koncepcje, tworzące przez lata podłoże obecnych zapatrywań w tej kwestii. Należałoby przypomnieć szczególne zasługi K. Engischa, który przeszło osiemdziesiąt pięć lat temu wskazywał na naruszenie tzw. zewnętrznej staranności (ostrożności) jako na cechę charakteryzującą czyny nieumyślne ${ }^{47}$. W nawiązaniu do starszych o sto lat wypowiedzi Stübla pojęcie zewnętrznej staranności działania i zaniechania K. Engisch wyjaśniał, odwołując się do charakterystyki zachowania niespełniającego tych wymogów jako działania „niebezpiecznego"48. Opisując formy staranności „,zewnętrznej”, autor wskazywał przede wszystkim na obowiązek zaniechania (zakaz) działań, które przy przestępstwach materialnych zdolne są z prawdopodobieństwem większym niż znikome sprowadzić zabroniony skutek ${ }^{49}$. Jak podnosił K. Engisch — w sytuacji niebezpiecznej obowiązek staranności nakazywać może niekiedy podjęcie określonych działań zapobiegających skutkowi ${ }^{50}$. Z ustaleń K. Engischa jasno wynikało, iż zachowanie, które nie wykazuje odpowiedniego stopnia prawdopodobieństwa spowodowania szkodliwego skutku, nie wypełnia znamion typu przestępstwa materialnego, nawet jeśli przyczyniło się do powstania zabronionej zmiany w świecie zewnętrznym ${ }^{51}$. Z normologicznych dociekań autora wynikało także, że norma nakazująca uniknięcie realizacji znamion typu czynu zabronionego (formułująca zakaz „spowodowania” szkodliwego skutku) jest identyczna z normą zabraniającą „zewnętrznie” niestarannego, nieostrożnego postępowania (norma „nie zabijaj” zawiera nakaz takiego ostrożnego zachowania, aby nie zabijać) ${ }^{52}$.

47 Szerzej na temat ustaleń K. Engischa w tej sprawie por. np. R. Dębski, Pozaustawowe..., s. 137 n; idem, O potrzebie..., s. 72-73.

${ }^{48}$ K. Engisch, Untersuchungen über Vorsatz und Fahrlässigkeit im Strafrecht, Berlin 1930, s. 269-270. Warto zaznaczyć, że pierwszych wypowiedzi podkreślających znaczenie zasad ostrożności dla konstrukcji przestępstw nieumyślnych dopatrywać się można także we wcześniejszych pracach innych autorów (por. J. Giezek, Naruszenie zasad ostrożności jako przesłanka urzeczywistnienia znamion przestępstwa nieumyślnego, „Państwo i Prawo” 1992, nr 1, s. 65 n.).

49 K. Engisch, op. cit., s. 283 n. Por. także R. Dębski, O potrzebie..., s. 72.

50 K. Engisch, op. cit., s. 290 n.

51 Jako zwolennik teorii negatywnych znamion przestępstwa (które określał jako znamiona „zawężające” typu czynu zabronionego) K. Engisch nie traktował znamienności i bezprawności jako odrębnych płaszczyzn wartościowania czynu. Szerzej na temat stanowiska K. Engischa por. R. Dębski, O potrzebie..., s. 73.

52 K. Engisch, op. cit., s. 333 n.; idem, Zur "Natur der Sache" im Strafrecht, [w:] Festschrift für Eb. Schmidt, red. P. Bockelmann, W. Gallas, Göttingen 1961, s. 102. Por. szerzej na ten temat R. Dębski, Pozaustawowe..., s. 137 n. 
Parę lat później — rozważając zespół znamion umyślnych typów przestępstw - H. Welzel klarownie wykazywał wadliwość założenia, że zachowanie wypełniające zespół znamion może być zredukowane do relacji kauzalnej „spowodowania" zabronionego skutku i podkreślał, że w żadnym wypadku znamienności czynu (wypełnienia znamion przestępstwa skutkowego) nie można identyfikować z przyczynowym sprowadzeniem skutku, ani bezprawia (społecznej szkodliwości) przestępstwa materialnego — z kauzalnym naruszeniem dobra chronionego ${ }^{53}$. Autor stanowczo sprzeciwiał się pojmowaniu ustawowych znamion, również określanych jako deskryptywne, jak ,zabija”, „niszczy”, „powoduje szkodę”, w sposób naturalistyczny, czysto kauzalny, bez uwzględnienia ich społecznego kontekstu i normatywnego znaczenia. Jego powszechnie znana myśl, że całe życie społeczne polega na użytkowaniu i zużywaniu dóbr prawnych, które nie mogą być zatem traktowane jak muzealne eksponaty, prowadziła autora do sformułowania tezy, że zakazane przez prawo może być nie każde (jakiekolwiek) naruszenie dóbr prawnych, lecz jedynie takie, którego można było uniknąć i które przekracza dopuszczalną społecznie miarę ${ }^{54}$. Można tu pominąć ustalenia autora związane z finalną nauką o czynie. Wskazać należy natomiast na istotny wkład jego rozważań w krytyczną analizę relacji sprawczej łączącej czyn z zabronionym skutkiem. Określając zachowania społecznie aprobowane jako „,społecznie adekwatne”, H. Welzel skonstruował normatywne kryterium służące do selekcjonowania czynów kauzalnych wobec zabronionego skutku i eliminowania działań niewypełniających znamion typu przestępstwa skutkowego ${ }^{55}$. Jak wiadomo, przeciwko Welzlowskiej koncepcji społecznej adekwatności (soziale Adäquanz) nie zabrakło w piśmiennictwie niemieckim głosów krytycznych ${ }^{56}$. Niepokój zwolenników tej koncepcji wywoływała również ewolucja zapatrywań samego autora co do miejsca społecznej adekwatności w strukturze przestępstwa ${ }^{57}$, szczęśliwie zakończona powrotem do tezy, iż społeczna adekwatność zachowania wyklucza możliwość uznania czynu za wypełniający znamiona typu czynu zabronionego ${ }^{58}$. Stwierdzić trzeba, iż mimo formułowanych wątpliwości i wahań ustalenia $H$. Welzla dotyczące wykluczenia znamienności zachowań społecznie aprobowanych, które - choć związane są z pewną „niebezpiecznością” dla dóbr prawnych — nie wypełniają jednak znamion typów czynów zabronionych, pozostawiły trwały ślad w doktrynie drugiej połowy XX wieku ${ }^{59}$.

53 H. Welzel, Studien zum System des Strafrechts, "Zeitschrift für die gesamte Strafrechtswissenschaft", (ZStW) 1939, Bd. 58, s. 528-529.

${ }^{54}$ Ibidem, s. 515-516.

55 Ibidem, s. 517 n. Por. również na ten temat R. Dębski, O potrzebie..., s. 73-74.

56 Por. na ten temat R. Dębski, Pozaustawowe..., s. 148-149.

57 Por. ibidem, s. $150 \mathrm{n}$.

58 H. Welzel, Das Deutsche Strafrecht, 11. Auflage, Berlin 1969, s. 57.

59 Por. np. H.-H. Jescheck, T. Weigend, Lehrbuch des Strafrechts. Allgemeiner Teil, Berlin 1996, s. $251 \mathrm{n}$. 
Choć nauka o obiektywnym przypisaniu skutku poszła znacznie dalej, formułując normatywne kryteria służące nie tylko wartościowaniu zachowań związanych kauzalnie ze skutkiem, lecz także kryteria oceny znaczenia samej relacji przyczynowej, to warto zauważyć, że zwolennicy formułowanej nierzadko w polskim piśmiennictwie tezy, iż do ustalenia odpowiedzialności za skutek wystarczy stwierdzenie cechy badanego zachowania jako warunku koniecznego (związku przyczynowego), a następnie ograniczenie zbyt szerokiego zakresu warunków w płaszczyźnie podmiotowej (zwłaszcza przez „kryterium winy”), w istocie odrzucają bez dostatecznej argumentacji ustalenia również innych, powszechnie uważanych w doktrynie za doniosłe, koncepcji poprzedzających naukę o obiektywnym przypisaniu skutku. Najbardziej niepokojące jest jednak całkowite pominięcie przez zwolenników wspomnianego stanowiska powszechnie uznawanych tez nauki o normie (do których wyraźnie odwołują się zarówno K. Engisch, jak i H. Welzel) oraz zlekceważenie — znaczących z punktu widzenia prewencyjnych i gwarancyjnych zadań przepisów karnych — funkcji informacyjnej i ostrzegawczej typu czynu zabronionego ${ }^{60}$. Nie trzeba wnikliwych analiz z zakresu teorii norm, aby stwierdzić, że norma postępowania nie zakazuje szkodliwego skutku, lecz podjęcia zachowania zagrażającego w sposób niedopuszczalny spowodowaniem szkody (określa zakaz nieaprobowanego prawnie postępowania niebezpiecznego dla chronionego dobra). Norma postępowania (norma sankcjonowana), do której odwołuje się przepis karny, nie służy jedynie do wyrażenia dezaprobaty odnośnie do spowodowanej zmiany w świecie zewnętrznym, lecz stanowi dyrektywę, zakaz (nakaz) określonego zachowania wobec chronionego przedmiotu. Nie ma wątpliwości, że norma prawa karnego (norma sankcjonująca) nie może wiązać kary kryminalnej wyłącznie z wystąpieniem szkodliwego skutku, niezależnie od dopuszczalności (społecznej aprobaty, legalności) zachowania powodującego szkodę albo jego wadliwości, naganności prawnej (bezprawności). Aprobata tezy, że do stwierdzenia bezprawności zachowania się wystarczy jedynie ustalenie jego (kauzalnego) przyczynienia się do zabronionego skutku, a niezbędnej korekty szeroko zakreślonej sfery odpowiedzialności poszukiwać należy dopiero na płaszczyźnie podmiotowej, oznaczałaby zgodę na przekazywanie mylnego komunikatu, wprowadzającego w błąd każdego z odbiorców tej informacji, nierzadko rozpoznającego bezprawność czynu przez wiadomość o jego karalności ${ }^{61}$. Odwoływanie się do „ograniczenia odpowiedzialności” w płaszczyźnie podmiotowej zakłada, iż mamy do czynienia z zachowaniami obiektywnie wadliwymi, przekraczającymi normę (bezprawnymi). Twierdzenie, że np. sprzedawca noży

60 Por. na ten temat np. R. Dębski, Kilka uwag o kryminalizacji i ustawowej określoności czynów zabronionych, [w:] Problemy wymiaru sprawiedliwości karnej. Księga jubileuszowa Profesora Jana Skupińskiego, red. A. Błachnio-Parzych et al., Warszawa 2013, s. 37.

61 Szerzej na ten temat por. np. R. Dębski, O potrzebie..., s. 67 n. 
w sklepie gospodarstwa domowego nie ponosi odpowiedzialności, dlatego iż w danych okolicznościach nie mógł przewidzieć, że nabywca zabije kupionym nożem człowieka, albo że obsługujący linię elektryczną nie mógł przewidzieć, że włączając prąd, spowoduje śmierć bezdomnego, który chroniąc się przed deszczem, włamał się do podstacji elektrycznej, sugeruje przekroczenia nieistniejących zakazów sprzedawania noży albo przesyłania prądu.

Dzisiaj już mało kto, stwierdza J. Majewski, w polskiej nauce prawa karnego ujmuje procedurę ustalania sprawstwa skutku w sposób czysto kauzalny ${ }^{62}$. Również w polskim orzecznictwie upowszechnia się przekonanie o konieczności stosowania kryteriów normatywnych ustalenia sprawstwa i stwierdzenia realizacji znamion przestępstwa skutkowego. J. Majewski podkreśla, iż sprzyjają temu unormowania obowiązującego kodeksu karnego (przepisy art. 2 i 9 § 2 k.k.). Uzasadniona jest — jak się wydaje — teza, że ,rezygnacja z tradycyjnych, zorientowanych kauzalnie modeli ustalania sprawstwa skutku na potrzeby odpowiedzialności karnej” została „częściowo po prostu wymuszona przez ustawodawcę” (co jednak ,nie przekłada się na powszechną aprobatę koncepcji obiektywnej przypisywalności skutku") ${ }^{63}$. Zatem w warunkach, gdy wciąż w naszym piśmiennictwie i judykaturze spotkać można wątpliwości, czy na potrzeby prawa karnego nie jest wystarczająca „stosowana z powodzeniem przez szereg lat koncepcja ekwiwalencji, z korekturą w zakresie zawinienia"64, nie powinny dziwić starania projektodawców z Komisji Kodyfikacyjnej Prawa Karnego proponujących wprowadzenie do kodeksu karnego przepisu wskazującego na potrzebę sięgania do kryteriów normatywnych obiektywnego przypisania skutku.

Trafnie podnosi J. Majewski, że stosowaną przez długie lata w polskich sądach procedurę ustalania sprawstwa za pomocą testu conditio sine qua non w sposób mniej lub bardziej zawoalowany (dodajmy: w sposób niekiedy mniej lub bardziej uświadomiony) „uzupełniano” o kryteria wartościujące, zwłaszcza w wypadkach gdy brak takiej korekty prowadził do wyników trudnych do zaakceptowania ze względów aksjologicznych lub kryminalnopolitycznych ${ }^{65}$. We współczesnym piśmiennictwie niemieckojęzycznym podkreśla się (czynią to również autorzy nastawieni krytycznie do nauki o obiektywnym przypisaniu skutku), że sama formuła conditio sine qua non — wbrew twierdzeniom o jednoznaczności i ,naukowym” obiektywizmie opartych na niej ustaleń — polega na wartościowaniu ${ }^{66}$. Niewątpliwie uznać trzeba, iż z punktu widzenia komunikatywności rozstrzygnięć sądowych i możliwości ich weryfikowania (zwłaszcza w ramach kontroli instancyjnej)

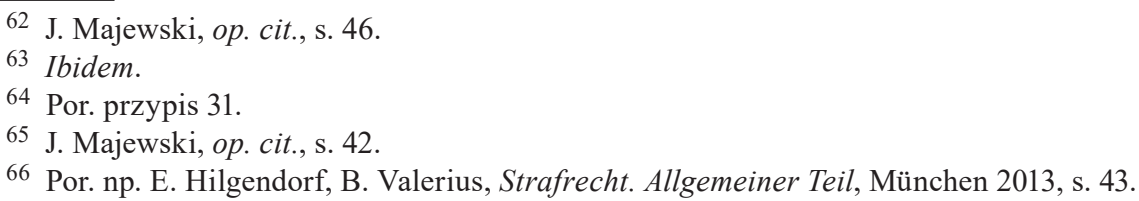


lepiej, aby w miejsce „ukrytego” wartościowania, stosowano (,ujawniane” w uzasadnieniach rozstrzygnięć) badanie okoliczności czynu oparte na znanych nauce i w istotnej części już uzgodnionych kryteriach przypisania skutku ${ }^{67}$.

$\mathrm{W}$ piśmiennictwie podnosi się, iż niektóre argumenty za zakotwiczeniem w kodeksie karnym koncepcji obiektywnego przypisania skutku, zawarte w uzasadnieniu przygotowanym przez Komisję Kodyfikacyjną (np. argument dotyczący braku podstawy w obecnym tekście kodeksu karnego do stwierdzenia obrazy prawa materialnego), można uznać za niedostatecznie przekonujące ${ }^{68}$. Najbardziej dyskusyjny wśród argumentów krytycznych formułowanych wobec uzasadnienia wydaje się najważniejszy zarzut, że dość naiwna jest wiara Komisji Kodyfikacyjnej, iż wprowadzenie do ustawy normy określającej reguły obiektywnego przypisania wyeliminuje z orzecznictwa nieprawidłowe rozstrzygnięcia, tj. orzeczenia, które nawiązują wprost do kauzalnie zorientowanego systemu prawa karnego ${ }^{69}$. Zarazem podnosi się — nie bez racji — iż pożądaną jednolitość orzecznictwa sądowego powinien kształtować przede wszystkim Sąd Najwyższy $i$ - w pewnym zakresie - sądy apelacyjne, a nie ustawodawca. Wydaje się jednak, iż jak uczy doświadczenie, nie jest pozbawione podstaw — wyrażone w uzasadnieniu projektu nowelizacji kodeksu karnego — oczekiwanie wpływu proponowanych przepisów na jednolitość orzecznictwa (wpływu istotnie większego niż oddziaływanie orzeczeń Sądu Najwyższego i sądów apelacyjnych).

Niełatwym problemem do rozważania pozostaje takie sformułowanie przepisu, aby nie przesądzało konstrukcji najbardziej spornych przesłanek obiektywnego przypisania, których ukształtowanie jest w nauce przedmiotem szczególnych kontrowersji i polemik. Moje uwagi dotyczące przepisów proponowanych przez Komisję Kodyfikacyjną w projekcie z dnia 5 listopada 2013 roku przedstawiałem już w innych opracowaniach ${ }^{70}$. W tym miejscu stwierdzić jedynie należy, iż najbardziej uży teczna wydaje się zwięzła norma wskazująca na konieczność badania, czy zabroniony skutek może być przypisany danej osobie jako jej dzieło i określająca związane z tym kryteria w sposób ogólny, nawiązujący do tzw. podstawowej formuły obiektywnego przypisania.

67 R. Dębski, O potrzebie..., s. 75.

68 Por. J. Giezek, P. Kardas, op. cit., s. 30-33.

69 Ibidem, s. 33.

70 R. Dębski, Czy zamieszczać..., s. 394-413; idem, O potrzebie..., s. 75-76; idem, O tzw. negatywnych przesłankach obiektywnego przypisania, [w:] Obiektywne oraz subiektywne..., s. $238-240$. 


\section{More on the proposal to include in the Criminal Code criteria of objective attribution of effect}

\section{Summary}

Polish jurists writing about criminal law as well as the case-law of the Supreme Court clearly display a growing acceptance of objective effect attribution. In German scholarship this theory has an extensive literature and fairly long history going back to the 1930 s (R. v. Honig). It owes its subsequent development to C. Roxin as well as numerous authors of German-language studies. In the Polish literature interest in the premises of the so-called Zurechnungslehre began much later, but it now has a substantial group of supporters. Some of them, however, including Prof T. Kaczmarek, oppose the proposal by the Criminal Law Codification Commission to introduce into the Criminal Code regulations indicating the need to apply the criteria of objective attribution of effect when determining whether a prohibited act is an act with criminal consequences. These authors point out that the catalogue of normative grounds for effect attribution is still debatable and the explanation of the criteria of objective effect attribution should better be left to jurists and case-law. Indeed, the German literature is far from any uniformity in the catalogue of criteria of objective effect attribution, with some authors rejecting objective attribution and looking for other concepts. This does not mean that these authors question the need to apply normative criteria when determining the causation of effect described in criminal law. However, the situation is different when it comes to Polish jurists and case-law. Opponents of objective effect attribution often highlight the advantages of applying the "simple" and "reliable" theory of equivalence of conditions and assume that the scope of necessary conditions may then be limited by the principle of guilt. Such a stance does not only denote a rejection of the assumption of objective effect attribution. It also fails to include conclusions stemming from other important concepts from the history of criminal law (e.g. from studies conducted by K. Engisch or $\mathrm{H}$. Welzl). At the same time it denotes a challenge to the findings from the now commonly accepted theory of norms and leads to a situation in which a court verdict sends a wrong message about the legal opinion on (the wrongfulness) of the analysed act. It would, therefore, seem useful to include in the Criminal Code a regulation which, without specifying in detail the various criteria of objective effect attribution, would point to the need to carry out a normative selection of causal links. Such a role could be played by a concise norm drawing on the so-called basic formula of objective attribution, a norm well-known to jurists.

Keywords: liability for effect, causal link, offence with criminal consequences, objective effect attribution, theory of equivalence of conditions, amendment of Criminal Code. 